\title{
A modernidade envolve o campo político: representações e práticas do processo eleitoral na Porto Alegre da década de 1920
}

Ricardo de Aguiar Pacheco

UFRGS

RESUM O

0 presente artigo pretende refletir sobre a conjuntura política vivida na cidade de Porto Alegrena década de 1920, marcada pela contestação ao controle político do PRR no estado, pelo processo de modernização das relações sociais característica da sociedade brasileira da década de 1920, e pela insuficiência das estruturas dedominação oligárquicas para dar conta dessa dinâmica social. Julgamos que tanto a continuidade administrativa do PRR, como a troca de intendente operada nos anos de 1924 e 1928, não podem ser tomadas como uma continuidade da política administrativa anterior. Para compreen dermos esse longo período de controle da intendência municipal julgamos necessário perceber tanto seu elemento de continuidade como as rupturas do período.

Palavras-chave: Campanha eleitoral; Clubes republicanos; Cultura política.

\section{ABSTRACT}

The article approaches the political conjuncture in the city of Porto Alegre (Rio Grandedo Sul) in the 1920's. It was characterized by: the plea to the political control by the PRR; the process of modernization of the social relations present in the Brazilian society; and the insufficience of the oligarchical structures of domination. The administrative continuity of thePRR during the exchange of mayor operated in theyears of 1924 and 1928 cannot be taken as a continuity of previous administrative politics. It is necessary to perceive the elements of continuity and of rupture to understand this long period of control in the city of Porto Alegre.

Keywords: Electoral campaign;

Republican clubs; Political culture. 
Uma micro-história da política local, para além de casos particulares, pode nos apontar regularidades e rupturas das tradições, das práticas e representações social mente articuladas pelos dirigentes políticos para legitimar a manutenção do poder institucional. Em 1896 teve início a gestão de osé M ontaury como intendente de Porto Alegre que, sucedido por O távio Rocha eAlberto Bins em 1924 e 1928, estabeleceu a longa administração do Partido Republicano Rio-Grandense (PRR) na capital do Estado, que se estendeu até 1937. Para interpretar o contexto político que deu sentido à continuidade administrativa, o presente artigo aborda as alterações o corridas nas estratégias de mobilização el eitoral ao longo da década de 1920.

Entendemos que nesse momento se configura uma conjuntura particular marcada pela profunda contestação ao controle político do PRR no Estado, pelo processo de modernização das relações sociais característica da sociedade brasileira da década de 1920, e pela insuficiência das estruturas de dominação oligárquicas para dar conta dessa dinâmica social. De tal sorte, julgamos que tanto a continuidade administrativa do PRR, como a troca de Intendente operada nos anos de 1924 e 1928, não podem ser tomadas como manutenção da mesma prática política e permanência das mesmas estratégias de mobilização eleitoral. Para compreendermos esse longo período de controle da inten dência municipal julgamos necessário perceber nessas trocas de candidatos tanto seus elementos de continuidade como suas rupturas. Tal observação pode nos apontar as práticas e representações utilizadas pelas direções partidárias para arregimentar e mobilizar o eleitorado numa comunidade urbana que vive o processo de modernização das relações sociais e econômicas para manter o controle do poder institucional.

O controle da intendência de Porto Alegre pelo PRR durante quarenta anos ininterruptos é tema já analisado por diversos autores. Para M argareth Bakos ocorreu um caso particular de "continuísmo administrativo" inédito tanto entre as capitais de estados brasileiros como entre os demais municípios do Rio Grande do Sul. Interpretando essa situação, argumenta a autora que durante a República Velha a capital tornou-se a "sal a de visitas" do Estado, devendo, naquele momento, espelhar todo o progresso alcançado pelo governo de inspiração positivista. ${ }^{1}$ Estudos como o de Luiz M aroneze mostraram que nas primeiras décadas do século XX a cidade de Porto Alegre se inseriu no processo de modernização como experiência social paradoxal. N ela, emergiram formas de sociabilidade particularmente marcadas pela multidão e pelo anonimato, pela vida coletiva e pela individualidade. ${ }^{2}$ Nesse cenário urbano podese esperar que as relações sociais existentes no interior do campo político tam- 
bém se tivessem alterado, cabendo às lideranças políticas a necessidade de um movimento de incorporação, ao processo, dos setores sociais que emergiam na urbe. Explicitou-se a necessidade da ad equação dos mecanismos de legitimação do poder institucional junto aos grupos sociais urbanos.

Como sabemos, os intendentes eram peças fundamentais dentro da dinâmica de legitimação institucional do sistema político montado durante a República Velha. M anter na Intendência M unicipal um nome de confiança das lideranças partidárias era fundamental para a reprodução do sistema de legitimação do exercício do poder institucional. Acima de qualquer política administrativa, as sucessivas reel eições de M ontaury estavam inseridas em um projeto de manutenção do controle político do PRR na capital do Estado. Já a ruptura dessa estratégia em 1924 precisa ser associada à necessi dade de cumprir os termos do Pacto de Pedras Altas, que significou o fim da reeleição não apenas para o presidente do estado, mas também para o cargo de intendente nos municípios do Rio Grande do Sul. ${ }^{3}$ Como salienta Helga Piccolo, 0 cenário sociopolítico da década de 1920 estava muito al terado em relação ao período de franca hegemonia do PRR no Estado:

A crise da década de vinte do atual século [vinte] denota a existência de interesses não atendidos, de outros grupos sociais - especialmente uma pequena burguesia e os trabal hadores urbanos que faziam reivindicações, que exigiam novos projetos políticos que pudessem incorporá-los. ${ }^{4}$

Ao estudar as eleições para intendente em municípios da zona de colonização alemã, durante a década de 1920, René Gertz mostra que, naquele momento, ocorreram significativas alterações na dinâmica da disputa política local. Nos jornais da colônia al emã se estabeleceu um forte debate sobre os nomes a serem indicados como candidatos. Essas comunidades passaram a reivindicar a eleição de nomes de origem alemã para a administração municipal. M esmo que o movimento de contestação, que também ocorreu em outros municípios da região de imigração, não se configure uma regra geral para as el eições da década de 1920 no estado, ao menos indica que existiam tensões sociais a serem resolvidas. ${ }^{5}$

Entendemos que o poder se legitima não apenas pela coerção física, mas também por um conjunto de representações e práticas sociais que dizem aos agentes sociais das possibilidades de ação política, das formas de codificar e interpretar as disputas políticas. ${ }^{6} \mathrm{O}$ entendimento dessa cultura política contribui para o entendimento das rupturas e continuidades existentes no processo 
histórico desse tempo-espaço. D esta forma, descrever como se desenvolveram as campanhas eleitorais para os cargos municipais ocorridas em 1920, 1924 e 1928 torna-se uma estratégia não apenas para identificar os mecanismos de arregimentação e mobilização do el eitorado urbano, mas também para evidenciar as recorrências e rupturas ocorridas nessa conjuntura particular.

Avaliando como a história política trata o tema das eleições, René Rémond evidencia diferentes abordagens possíveis. Elas podem ser um indicador do "espírito público" das comunidades, uma vez que evidenciam o nível de mobilização das comunidades e suas opiniões. Afirma ainda que, alargando a observação para o período de campanha eleitoral, podemos perceber como o discurso dos partidos se relaciona às expectativas dos eleitores. ${ }^{7}$ N esses momentos podemos perceber as estratégias utilizadas pelos diferentes grupos sociais para apresentar suas concepções ao conjunto da comunidade elegitimar o controle do aparelho estatal. M omento de mediação de interesses e significados, as eleições podem ser tomadas como uma porta de acesso ao código operado pelos agentes sociais para codificar e interpretar o processo político. Estudos de antropologia também apontam para abordagens diferenciadas do fenômeno político e, particularmente, das campanhas eleitorais. Segundo M oacir Palmeira e M arcio Goldman, diversos estudos etnográficos apontam para a percepção das eleições e das campanhas eleitorais como espaços de mediação simbólica. N essa abordagem, o campo de análise é ampliado para estabelecer as relações desse fenômeno social com as representações particulares de cada grupo, com a dimensão comunitária e familiar dos agentes envolvidos: “O u seja, em lugar de partir de supostas 'faltas' ou 'carências' do eleitorado ou do sistema como um todo, busca-se apreender o que há aí de específico e de positivo". ${ }^{8}$ Fundamentados no entendimento antropológico de cultura, propomos uma observação da dinâmica eleitoral que evidencie não apenas os resultados el eitorais, mas também os significados atribuídos a essa prática social.

A bibliografia existente sobre a legislação eleitoral da República Velha insiste em afirmar que esta em pouco difere do último regimento do Império. A Constituição republicana de 1891, no que tange à questão el eitoral, adotou os preceitos federalistas que permitiam ampla autonomia às unidades. $\mathrm{Na}$ questão eleitoral, a carta limitou-se a regulamentar os critérios para que o cidadão pudesse se inscrever para o exercício do voto. Como analisa Victor Nunes Leal, as definições da Constituição Federal sobre o processo eleitoral basicamente se limitavam aos critérios para o exercício do voto. Eram considerados eleitores os brasileiros naturais ou naturalizados, homens, com idade acima de 21 anos e alfabetizados. 0 poder central estava limitado a pro- 
mover as eleições federais, ficando cada estado autorizado a regulamentar seus próprios pleitos. ${ }^{9}$

Frente a essa situação de autonomia dos entes federados, surgiram diferentes legisl ações el eitorais estaduais e municipais. Como apontado por Jairo M arconi N icolau, havia uma ampla liberdade para a criação de diferentes legislações eleitorais nos Estados. ${ }^{10}$ No caso particular do estado do Rio Grande do Sul, que ora nos interessa, essa licença constitucional significou uma legislação el eitoral estadual muito particular, promulgada em 1897. De acordo com estudo de H él gio Trindade, estabelecia-se que as eleições no Rio Grande do Sul seriam realizadas através do voto a descoberto. O u seja, eram criados mecanismos legais que tornavam evidente para qual candidato o eleitor havia confiado seu voto. ${ }^{11}$

Tal situação somente se alterou com o processo revolucionário de 1923. Detonada com a derrota da candidatura oposicionista de Assis Brasil ao governo do estado e a posse de Borges de M edeiros em seu quinto mandato, essa revolta armada teve seu fim com o Pacto dePedras Altas. Através desse acordo, ficaram asseguradas diversas garantias à oposição. A principal delas foi a alteração da Constituição Estadual, "proibindo a reeleição do presidente [ do estado] para o período imediato. I êntica disposição quanto aos intendentes". M as também ficava acertada a "adaptação às elei ções estaduais e municipais da legislação el eitoral federal", instituindo garantias à lisura dos processos eleitorais no estado e pondo fim ao voto a descoberto. ${ }^{12}$

Os termos desse acordo al teraram a dinâmica da disputa eleitoral e colocaram ao Partido Republicano a necessidade de trocar os candidatos aos cargos do executivo estadual e dos municípios. Essa mudança não foi pequena na percepção dos contemporâneos, tanto que passou a ser explicada pela imprensa às vésperas da eleição. O Correio do Povo publicou longo texto explicativo no qual dizia que "a cédula deve estar em invólucro fechado, sem distintivo al gum, trazendo sempre a indicação da el eição de que se tratar". ${ }^{13} \mathrm{~N}$ essa conjuntura, à oposição coube a percepção de que poderia disputar as eleições em condições mais favoráveis; para a situação, significou a necessidade de se legitimar o exercício do poder institucional através de um processo eleitoral sem fraudes ou instrumentos de controle. Tanto para um quanto para os outros, portanto, colocou-se a necessidade de estabel ecer estratégias mais eficientes para disputar o voto do el eitorado urbano.

Segundo os dados do censo de 1920, 75,5 por cento da população total em nível nacional não sabia ler e escrever. Como vemos na Tabela 1, no Rio Grande do Sul essa taxa estava em 61,1 por cento, e na sua capital, Porto Alegre, caía 
para 42,4 por cento. Comparando esses com os percentuais de outras capitais, vemos que Porto Alegre seguia a tendência de apresentar índices de alfabetização acima das médias nacionais e dos seus respectivos estados. ${ }^{14}$ Ainda seguindo esses números do censo de 1920, Porto Alegre possuía uma população total de 179.263 habitantes, sendo a população masculina de 89.081 pessoas. A legislação permitia o exercício de voto aos homens alfabetizados acima dos 21 anos, mas somente tem-se recorte dos dados da população com 15 anos ou mais. Entre estes, os homens alfabetizados, segundo o levantamento, totalizavam 36.425 habitantes..$^{15}$ Por esses dados, percebemos que, em 1920, estariam aptos a se inscrever como eleitores em Porto Alegre menos de vinte por cento da sua população. Seguindo os mesmos critérios, constatamos que esse índice estava bem acima da média nacional, de dez por cento. Frente a outras capitais, observamos que Porto Alegre apresentava um eleitorado potencial bem acima dos índices de 11,3 por cento do Distrito Federal e de 13,9 por cento de São Paulo/capital, mas não muito diferente dosíndices identificados para outras capitais de estado, como Salvador e Belo H orizonte, com 21,4 e 22,4 por cento, respectivamente. Esses dados nos permitem apontar que a comunidade política de Porto Alegre, aqueles que poderiam participar da legitimação do exercício do poder institucional através dos processos eleitorais, aproximava-se dos vinte por cento da população.

\section{Tabela 1}

Estimativa da população habilitada a ser el eitor da cidade de Porto Alegre em comparação com o Brasil, com o estado do Rio Grande do Sul, cidades do Distrito Federal, São Paulo, Salvador e Belo Horizonte

\begin{tabular}{lrrrrr}
\hline & $\begin{array}{c}\text { População } \\
\text { total }\end{array}$ & $\begin{array}{c}\text { Não sabem } \\
\text { ler nem } \\
\text { escrever }\end{array}$ & $\begin{array}{c}\text { \% de } \\
\text { sobre população } \\
\text { total }\end{array}$ & $\begin{array}{c}\text { Homens de } \\
\text { 15 anos ou } \\
\text { mais que sabem } \\
\text { ler e escrever }\end{array}$ & $\begin{array}{c}\text { \% estimada } \\
\text { da População } \\
\text { habilitada a } \\
\text { ser eleitor }\end{array}$ \\
\hline Brasil & 30.635 .605 & 23.142 .248 & $75,5 \%$ & 3.247 .850 & $10,6 \%$ \\
\hline RS & 2.182 .713 & 1.334 .771 & $61,1 \%$ & 335.121 & $15,4 \%$ \\
\hline Porto Alegre & 179.263 & 74.297 & $41,4 \%$ & 36.425 & $20,7 \%$ \\
\hline Rio deJaneiro/DF & 1.559 .371 & 1.173 .975 & $75,3 \%$ & 176.557 & $11,3 \%$ \\
\hline São Paulo/Capital & 579.033 & 241.331 & $41,7 \%$ & 80.698 & $13,9 \%$ \\
\hline Salvador & 283.422 & 124.927 & $44,1 \%$ & 60.647 & $21,4 \%$ \\
\hline Belo Horizonte & 55.563 & 21.885 & $39,4 \%$ & 12.462 & $22,4 \%$ \\
\hline
\end{tabular}

Fonte: DIRECTORIA GERAL DE ESTATÍSTICA. Synopse do recenseamento realizado em 1 set. 1920. 
M as preencher os critérios legais não bastava para participar do processo eleitoral. 0 voto não era obrigatório, e se cada cidadão cumprisse os requisitos para se tornar el eitor deveria se inscrever voluntariamente. Cruzando o número de votos válidos com o da população, como apresentado na Tabela 2, percebemos que apenas 3,8 por cento da população total da cidade votou para intendente municipal no pleito de 1920. Atualizando a população da cidade por projeções de crescimento frente ao censo de 1940, estimamos uma participação de 4,8 e de 3,8 por cento da população nas eleições municipais de 1924 e de 1928, respectivamente.

Tabela 2

Votos válidos nas eleições majoritárias em Porto Alegre na década de 1920

\begin{tabular}{llccc}
\hline Cargo & $\begin{array}{c}\text { População total } \\
\text { (projetada } \\
\text { a partir do } \\
\text { censo de } \\
\text { 1920) }\end{array}$ & $\begin{array}{c}\text { Total de votos } \\
\text { a válidos (com } \\
\text { base nos resultados } \\
\text { eleitorais em } \\
\text { A Federação) }\end{array}$ & $\begin{array}{c}\text { \% de votantes } \\
\text { sobrea } \\
\text { população } \\
\text { total }\end{array}$ \\
\hline 1920 & Intendente M unicipal & 179.263 & 6.817 & $3,8 \%$ \\
\hline 1922 & Presidente da República & 187.236 & 7.816 & $4,2 \%$ \\
\hline 1922 & Presidente Estadual & 187.236 & 11.782 & $6,2 \%$ \\
\hline 1924 & Intendente M unicipal & 195.566 & 9.515 & $4,8 \%$ \\
\hline 1926 & Presidente da República & 204.265 & 8.441 & $4,1 \%$ \\
\hline 1928 & Intendente M unicipal & 213.352 & 8.121 & $3,8 \%$
\end{tabular}

Nota: Os dados para 1920 são extraídos do Censo desse ano. Os demais anos são estimados a partir de uma taxa de projeção da população de 2,2\% ao ano feita com base no Censo de 1940, seguindo proposta utilizada por Paul Singer. A população do ano de 1928 foi calculada com base na população dos distritos que permaneceram como Porto Alegre após

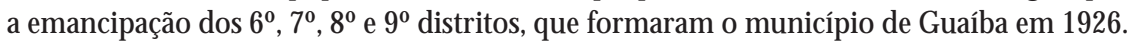

Esses índices não representam, efetivamente, uma participação maciça da população urbana, mas ainda assim, estão acima daqueles identificados por outros estudos para a partici pação nas eleições presidenciais do período. Segundo os dados sistematizados por Guerrei ro Ramos, os percentuais de votantes para as eleições presidenciais da República Velha oscilavam entre 3,4 e 1,4 por cento da população total. Apenas a eleição de 1930 superou esses ín- 
dices, chegando a 5,6 por cento da população total. ${ }^{16}$ Comparando esses números com a Tabela 2 vemos que, na eleição presidencial de 1922, enquanto o percentual nacional de participação foi de 2,9 por cento, em Porto Alegrea taxa foi de 4,2. Já no pleito de 1926 o índice geral foi de 2,3 por cento, enquanto na cidade esteve em 4,1. Tais números demonstram que nessa urbe o processo el eitoral mobilizava um contingente ligeiramente acima das medidas.

A legislação el eitoral descentralizada também permitiu a existência de um cronograma eleitoral muito movimentado. Os processos eleitorais federais, estaduais e municipais corriam segundo calendários distintos e desarticulados entre si. Na cidade de Porto Alegre, onde estamos focando nosso estudo, corriam cinco calendários eleitorais paralelos. I nicialmente temos o cal endário das eleições federais para presidente e vice-presidente a cada quatro anos. As eleições para senador e deputado federal seguiam outro quadriênio e, como não havia suplência, sempre que ocorria vacância de algum posto parlamentar eram realizadas el eições avulsas, como em março de 1923. Independente desse primeiro cronograma corria o calendário estadual, que previa el eições a cada cinco anos para presidente de estado e as el eições para a escolha dos membros da Assembléia de Representantes do Estado a cada quatro. Paral elamente a esses dois processos no Rio Grande do Sul, cada município promulgava sua própria legislação eleitoral, tendo como regra geral o mandato de quatro anos. Eram eleitos intendentes e, a partir de 1924, também os vice-intendentes juntamente com os consel heiros municipais que, no caso de Porto Alegre, eram nove.

Como visto, esses calendários simultâneos criavam uma sucessão praticamente ininterrupta de processos eleitorais. Durante a década de 1920 ocorreram na cidade treze pleitos em datas diferentes. Por vezes, mal eram divulgados os resultados de uma votação já se iniciavam os trabal hos de inscrição de el eitores para a próxima. Essa quantidade de el eições surpreende não apenas por sua grandeza, mas também pelo contexto autoritário em que estão inseridas. Processos eleitorais são momentos de mobilização política, o que permite apontar para a existência de uma movimentação constante em torno das eleições e, portanto, da legitimação do poder institucional. O correu, contudo, que as estratégias de arregimentação e mobilização el eitoral em Porto Alegre não seguiram as mesmas ao longo da década de 1920. Para avaliar a dinâmica desses momentos optamos por acompanhar as campanhas eleitorais dos três pleitos municipais do período. 
José Montaury: A Última REELEIÇÃO

Frente a essa estratégia de manutenção do poder institucional através das sucessivas reel ei ções, a indicação de J osé M ontaury para o pleito municipal de 1920 não deve ter surpreendido a população de Porto Alegre. Para informar a comunidade dessa candidatura, A Federação publicou, no canto superior direito da primeira página da edição do dia 21 de agosto de 1920, um anúncio com tipos em negrito e emoldurado. ${ }^{17}$ Tanto no anúncio da primeira página como na nota do interior do jornal vê-se que a proclamação é feita pelo líder político local, o Cel. M arcos de Andrade. ${ }^{18} \mathrm{M}$ as os dois textos mencionavam a expressa autorização do chefe republicano Borges de M edeiros. O u seja, tal como é percebido pela historiografia para outras localidades do estado no mesmo período, o chefe partidário e governador do estado era a instância de definição das candidaturas republicanas. ${ }^{19}$

O candidato não era relacionado a nada além da própria atividade na intendência, atividade que exercia já por doze anos. Os conselheiros eram apresentados através de suas atividades profissionais, sem nenhuma menção à atuação política e partidária. Logo, entendemos que a atuação profissional desses agentes era o elemento importante para legitimar a indicação de seus nomes para assumirem a Intendência e o Conselho M unicipal. Entre os candidatos ao consel ho vemos um advogado e um médico frente a três industrialistas, um comerciante, um capitalista e um proprietário. Somando-se a esses últimos um operário, tem-se um total de sete nomes ligados às atividades econômicas típicas do processo de modernização das sociedades, frente a dois nomes ligados às atividades tradicionais. Numa sociedade em que doutores, advogados ou médicos, eram altamente prestigiados no mundo político, essa presença maior de nomes ligados às atividades industriais e comerciais não pode ser desconsiderada. N esse momento de industrialização e dinamização econômica e social da cidade de Porto Alegre, podemos entender que essa nominata apresentava uma seleta dos grupos sociais urbanos. Estamos, portanto, diante de uma chapa que, de certa forma, espelhava a força dos grupos sociais urbanos emergentes.

Desde então A Federação iniciou a publicação de uma série de artigos em que se propunha a "analisar a significação da merecida reel ei ção" do intendente J osé M ontaury. N esses artigos eram apontadas as virtudes e méritos de sua administração. Eram destacados justamente o equilíbrio fiscal e as ampliações dos serviços urbanos efetuados na cidade. Já para justificar a el eição dos conselheiros, o discurso foi outro, visto que nenhum deles concorria à 
reel eição. 0 discurso do jornal, ao mesmo tempo em que se defendia a manutenção do intendente, sustentava como imperativo a total substituição dos consel heiros municipais, numa ginástica argumentativa como a que segue:

Se para a reeleição do administrador, desde que ele corresponda plenamente às necessidades públicas, existem essas razões indeclináveis, tanto de natureza doutrinária como de ordem prática, para os corpos legislativos ou orçamentários, que são também aparel hos de fiscalização, o critério da renovação periódica, conquanto não seja também necessária, é pelo menos aconselhável, como acontece, no caso corrente, com o Consel ho M unicipal. ${ }^{20}$

A retórica discursiva, como se vê, não está muito preocupada em manter a coerência de pensamento, visto que se defende simultaneamente a permanência e a alternância dos nomes para os cargos. Fica evidente que a intenção da argumentação éfazer calar qualquer crítica, seja pela permanência dos candidatos, seja pela troca dos nomes indicados. Tanto a reeleição do intendente como a el eição dos conselheiros significavam a continuidade de um projeto político administrativo. Os candidatos eram individualmente legitimados por sua representatividade social, ao passo que a qualidade da chapa republicana era atribuída justamente à diversidade de setores sociais representados no interior da nominata. Essa vinculação social, contudo, era atribuída a uma atuação profissional, enão propriamente a uma ação política.

Efetivamente, não se pode crer que uma campanha el eitoral se fizesse sem nenhuma atividade coletiva envolvendo os candidatos e os eleitores. $M$ as os jornais do período não fizeram nenhum registro sobre essas reuniões, comícios ou qualquer outra atividade. Dessa forma, podemos entender que para essa comunidade tais eventos não eram significativos para a campanha. Constituindo-se A Federação o principal veículo de divulgação das candidaturas republicanas, é possível tomar os redatores do jornal como os principais responsáveis pela propaganda eleitoral. Era o jornal o instrumento não apenas de comunicação partidária, mas também de difusão dos elementos responsáveis pela codificação e interpretação do processo de disputa el eitoral para o conjunto da comunidade política.

Contrastando com o entusiasmo do jornal republicano, as edições do Correio do Povo do mesmo período praticamente desconheceram o pleito para a Intendência e o Conselho M unicipal de Porto Alegre. A penas no dia da votação surgiu uma nota apresentando os nomes dos candidatos republicanos e comentando que "a oposição que tinha um representante no conselho, 
cujo mandato está a findar, não comparecerá, hoje, às urnas, visto não haver apresentado candidato nem para o cargo de intendente nem para o conselho municipal". ${ }^{21}$ Como observamos, a abstenção da oposição no pleito municipal foi um movimento deliberado. Os motivos para esse afastamento, mesmo não estando explícitos, podem ser associados ao pouco espaço político para a oposição na política regional. M as o maior impacto social dessa omissão foi a ausência do debate eleitoral ou sua redução a um monólogo republicano, não envolvendo demais setores da sociedade.

Segundo a ótica da folha republicana, o pleito transcorreu "na melhor ordem, no meio de grande entusiasmo".22 Uma vez que não existia outra chapa disputando as vagas com os candidatos republicanos, não haveria razão para tumultos. M encionar como "extraordinário o número de eleitores que compareceram às urnas", nesse contexto, não significava dizer que o processo teve ampla participação da população. Entendemosquea menção a essa quantidade abstrata era uma forma de reforçar a legitimidade do processo el eitoral. Já o Correio do Povo limitou-se a publicar o resultado da votação, furtando-se a fazer qualquer comentário a respeito de sua dinâmica. E nem um, nem outro jornal fez menção ao uso de expedientes fraudulentos no processo eleitoral ou de uso da violência. Somado e medido tudo isso, podemos tomar os resultados divulgados como manifestação da opinião, senão do conjunto da população urbana, pelo menos dos eleitores republicanos que compareceram.

0 resultado dessa votação que deu vitória aos candidatos republicanos não apresentou nenhuma surpresa, uma vez que não existiam candidatosoposicionistas. $M$ as outros detalhes merecem destaque para que se possa observar o significado social do processo eleitoral. Observamos que houve uma preocupação de garantir votos não apenas para os candidatos indicados ao conselho, mas também para igual número de suplentes. Notamos ainda que tanto os conselheiros como os suplentes obtiveram votações muito próximas entre si : 6.700 votos para os consel heiros e 110 votos para os suplentes. Resultado mais curioso ainda quando observamos que os suplentes tiveram todos os seus votos no quarto distrito eleitoral. Isto demonstra um controle desse eleitorado urbano por parte do PRR. ${ }^{23}$

Em seu conjunto, a eleição de 1920 foi semelhante ao que a bibliografia aponta para o conjunto do estado no período. O PRR se mostrava disciplinado e obediente ao chefe político. Já a oposição tinha limitada possibilidade de disputa. 0 conjunto de silêncios sobre a campanha eleitoral faz ouvir o pequeno valor atribuído ao processo eleitoral por essa comunidade política. N essa medida, a reeleição perdia força como estratégia de legitimação do po- 
der institucional. E o processo eleitoral, como prática social, tinha pouco significado para o conjunto da comunidade de Porto Alegre.

Dessa forma, entendemos que a sétima reel eição de José M ontaury para a intendência municipal de Porto Alegre se mostrava como uma última rodada da estratégia política do PRR, de manutenção do poder institucional no município, através do estatuto da reel eição. Sem desejar estabelecer paralelismo, mas para percebermos as recorrências existentes, faz-se forçoso lembrar que, também no ano de 1922, a oposição não reconheceu os resultados eleitorais do pleito estadual e se colocou em armas mostrando o esgotamento do arranjo institucional vigente. Como uma prática social responsável por conferir legitimidade ao exercício do poder institucional, as eleições e sua dinâmica estão inseridas em uma rede de significados. N o caso agora apresentado, não se pode negligenciar a real ização da votação e a presença dos eleitores mesmo não havendo disputa. A existência de agentes sociais dispostos a investir seu tempo e seu prestígio social na participação nesse processo, como candidatos ou como eleitores, aponta que essa prática tinha al gum significado social.

\section{OTÁVIO ROCHA: OS RESULTADOS DA MODERNIZAÇÃO}

Uma vez alteradas as bases da organização social frente ao processo de modernização da cidade, ocorreu uma fragilização dos arranjos políticos institucionais. Frente ao Pacto de Pedras Altas ficou colocada a possibilidade ou necessidade, tanto aos republicanos como aos oposicionistas, de alterar as práticas e representações vinculadas ao processo el eitoral de maneira que elas viessem a estabelecer a legitimidade social para o exercício do poder institucional.

Não podendo seguir com a estratégia da reeleição o PRR apresentou O távio Rocha como candidato à Intendência M unicipal eAlberto Bins como candidato a vice. Para Walter Spal ding o primeiro “já vinha de longa data, militando na política republicana de Estado, quer como jornalista (redator deA Federação), quer como deputado". Sobre o segundo diz que "a grande indústria metalúrgica, fabricação de camas de ferro, cofres - os famosos cofres Berta - , além de outros produtos de ferro para os mais variados fins, deuIhe o verdadeiro senso administrativo". ${ }^{44}$ Como percebemos tanto um, com uma vida partidária, quanto outro, com uma carreira empresarial, representavam idéias e valores modernizadores. ${ }^{25}$ 
Antevendo um confronto eleitoral com a oposição nesse pleito, o PRR deu início a uma intensa atividade de campanha. No dia 14 de julho, foi organizada uma festa cívica seguida de reunião partidária para o anúncio dos seus candidatos ao pleito municipal. Para tal, nos dias que antecederam a essa atividade, publicou-se o convite na primeira página de A Federação:

Convidamos ao partido republicano da capital para homenagem cívica que será prestada a 14 de julho próximo, às 15 horas, ao imortal patriarca Dr. Júlio de Castilhos, junto ao monumento da praça M arechal Deodoro.

Outrossim, convidamos para a sessão que, no teatro São Pedro, logo em seguida, realizará a nossa gloriosa agremiação partidária, para a escol ha dos candidatos aos cargos de intendente e vice-inten dente e consel heiros municipais, na eleição de 28 de setembro vindouro. ${ }^{26}$

Como se lê nesse chamamento, tratava-se de duas atividades distintas, mas diretamente relacionadas entresi: uma, a "homenagem cívica” ao patriarca junto ao monumento em sua memória; outra, a "sessão partidária" para a escolha dos candidatos republicanos ao pleito municipal no grande teatro da cidade. Podemos propor que a primeira atividade, rememorar o líder morto, acionava um conjunto de signos e significados que seguramente passavam a ser explorados no segundo momento, o da aclamação dos candidatos republicanos. ${ }^{27}$ Fica evidente, nessa dupla atividade dos republicanos, a utilização de um código para a transmissão de uma mensagem sobre como se esperava que os el eitores se comportassem. Ao associar uma plenária partidária com uma homenagem ao líder morto, seguia-se o lema positivista "os mortos governam os vivos". N esse bordão, lê-se a indicação de que as decisões do presente devem ser tomadas com base na memória do passado. A homenagem está voltada ao vulto do passado, mas imaginariamente remete à obediência devida pelos partidários ao chefe político vivo. Por seu turno, a escolha da data referente ao aniversário da Carta Constitucional reforçava o apego a esse texto legal justamente no momento em que ele havia sido questionado e reformado pela pressão política da oposição. O u seja, esse ato pode ser interpretado como uma reafirmação do programa histórico do PRR, corporificado no texto constitucional castilhista. Ao utilizar a praça central da cidade e as dependências do teatro São Pedro, o ato político ganhava uma dimensão e visibilidade de atividade pública. A proclamação da chapa republicana tornou-se uma manifestação coletiva de aclamação.

Diferentemente do processo anterior, quando o anúncio foi feito pelo 
jornal, nesse momento se fizeram presentes as diferentes lideranças partidárias municipais. Segundo o relato dessa atividade publicado no jornal, estavam presentes o intendente J osé M ontaury e os membros da Comissão Executiva municipal Genes Bento, Sinval Saldanha, Frederico M esquita e Otávio Rocha. E chama a atenção a presença do próprio Borges de M edeiros. M as também se deve destacar a participação do "grande público". M esmo não tendo como aferir a quantidade de partidários ali presentes, essa menção já serve de indicativo do envolvimento dos partidários na legitimação dos candidatos republicanos. ${ }^{28}$ Dessa maneira, inferimos que 0 conjunto dos republicanos, enão apenas as lideranças, mostrava para a comunidade política o seu compromisso com a nominata apresentada. Entendemos, sobretudo, que ocorreu uma alteração do significado do processo eleitoral. De uma formalidade institucional o pleito passa a ser percebido como momento de efetiva disputa política. As atividades de campanha, antes desprestigiadas, agora ganhavam ares de movimento social. De mero debate jornalístico passava à manifestação pública em torno dos programas partidários.

Outro indicativo dessa alteração de significado do processo eleitoral foi a forma como as candidaturas eram divulgadas por A Federação. Diferentemente do pleito anterior, nesse momento o jornal partidário descreveu detaIhadamente o evento. Foram mencionados os nomes dos presentes, narrados os acontecimentos e transcritos os discursos pronunciados do palco. Segundo o longo relato do jornal partidário, após os discursos das lideranças, um orador foi chamado para apresentar ao público os nomes indicados como candidatos do PRR ao pleito municipal. 0 discurso proferido quando do lançamento das candidaturas chama a atenção por diferentes aspectos. ${ }^{29}$ Destacamos, inicialmente, que o PRR indicou sete nomes para as nove vagas do Consel ho M unicipal. M as não se pode entender esse movimento como uma concessão do PRR, visto que o Pacto de Pedras Altas estabel ecia o compromisso de não serem apresentadas chapas completas para permitir a representação da oposição.

Diferentemente do pleito anterior, quando se apresentaram os candidatos por suas profissões, agora se mencionava a atuação política e seu envolvimento com as atividades partidárias através das associações políticas. $0 \mathrm{Dr}$. Egydio Hervé era dado a conhecer como membro do consel ho fiscal do Centro Republicano Júlio de Castilhos, e o Dr. Jayme da Costa Pereira foi referido como presidente do Clube $\mathrm{M}$ arcos de Andrade. Essas duas associações republicanas tinham um papel importante na dinâmica de mobilização dos partidários, pois promoviam inúmeras atividades de mobilização política e 
congregavam inúmeros eleitores republicanos. Ser seu dirigente significava, sem dúvida, uma estreita vinculação com os eleitores republicanos que ali se reuniam. Já Vigo Tompes Collin era lembrado como tesoureiro da Liga dos Operários Republicanos, outra associação política vinculada ao PRR. M as era destacada ainda sua traj etória na prestigiada Federação O perária do Rio Grande do Sul (FORGS). Para os republicanos, esse operário era um integrante vaIoroso que já assumira responsabilidades junto ao partido. M as de outra parte, ao ressaltar esse último aspecto, percebemos que el e teve sua candidatura legitimada por sua representatividade junto a esse grupo social urbano particular que é o operariado. Da mesma forma, apontou-se Pedro João Gonçalves da Silva D ossena como presidente da Associação dos Varejistas da capital. N ovamente percebemos a val orização das vinculações políticas exteriores ao partido como elemento de legitimação da candidatura. Tomando apenas esses casos, seria precipitado afirmar que os outros nomes também fossem representantes de grupos sociais apresentados ao partido. M as não se pode descartar a importância das posições de presidente, tesoureiro e fiscal atribuídas aos outros candidatos, nem ignorar que a ocupação de um desses postos já implicava uma escolha no interior da associação.

A importância dessas associações partidárias no processo eleitoral também pode ser percebida através do papel que elas desempenharam ao longo da campanha. Diferentemente de 1920, quando o convencimento do eleitorado se restringia ao jornal, em 1924 A Federação publicou a ocorrência de nove comícios eleitorais. Depois desse lançamento ocorreram vinte atividades de campanha voltadas para públicos distintos entre si. M as sua sistemática foi recorrente: em todos esses eventos estavam presentes, além da executiva municipal do partido, um ou vários candidatos. Eram proferidos discursos tanto por esses como pelo representante da associação que os recebia. Se em 1920 a campanha estava a cargo do jornal do partido, em 1924 as associações políticas assumiram um papel fundamental na arregimentação e mobilização el eitoral. Talvez isso seja uma primeira explicação para o esforço do partido em justificar as candidaturas através do envolvimento desses nomes com elas.

Frente às garantias do Pacto de Pedras Altas, a oposição também se articulou para disputar a Intendência M unicipal de Porto Alegre em 1924. Logo após a contagem de votos da el eição de deputados federais e senadores, realizada em maio, a oposição iniciou seus preparativos para disputar o pleito municipal de setembro. N esse sentido, o primeiro movimento do Partido Federalista foi a publicação de um anúncio publicitário no Correio do Povo chamando para o alistamento el eitoral: 
Não há, pois, que perder tempo. Alistai-vos quanto antes e fazei alistar com urgência os vossos amigos e companheiros. Para isso estarão a vossa disposição os diversos centros oposicionistas da capital, inclusive o Diretório do Partido Federalista - rua Andrade N eves $n=8{ }^{30}$

Na seqüência a Aliança Libertadora também fez publicar no Correio do Povo uma série de artigos, debatendo com os redatores de A Federação sobre a instituição do voto secreto e o imperativo de adotar tal instrumento ainda nesse pleito. ${ }^{31}$ Tais artigos evidenciam que o grande debate político do momento ainda era sobre as regras do processo, sobre as mudanças no arranjo institucional e não propriamente sobre programas administrativos.

O bserva-se ainda que a decisão da oposição de apresentar candidatos ao pleito municipal, tal como entre os republicanos, ocorreu através de uma “sessão plenária". Dessa forma, as lideranças oposicionistas, embora presentes, simbolicamente também transferiram o poder de decisão ao conjunto dos partidários. Procuraram, assim, dar a entender que a nominata não correspondia ao desejo de um pequeno grupo de lideranças partidárias, mas do conjunto dos membros da oposi ção. Pelas notas jornalísticas sobre o processo sucessório municipal percebe-sea oposição lançando candidaturas para oscargos de intendente e de vice-intendente, mas também para cinco conselheiros municipais. Essa chapa deixava evidente a intenção da oposição de disputar os cargos do executivo municipal. Ao mesmo tempo, o número reduzido de candidatos ao Conselho, cinco nomes para nove vagas, apontava para a intenção de usar o artifício do voto acumulado. E já no dia seguinte à indicação dessas candidaturas, surgiram convites para comícios de campanha nas associações da oposi ção. De forma muito similar às atividades do Partido Republicano, esses comícios espalhavam-se pela cidade utilizando as sedes das associações

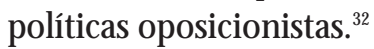

Através das notícias divulgadas nos jornais, tem-se uma idéia da mobilização social ocorrida em torno desse pleito. Para o PRR, o convencimento não estava mais a cargo apenas do jornal, não envolvia somente uns poucos dirigentes. Houve sim, uma mobilização e articulação do conjunto dos partidários através das associações políticas e de suas atividades de campanha. Acompanhando as notas divulgadas pelo Correio do Povo, percebe-se que a movimentação da oposição foi mais tardia e, talvez por isso, de menor intensidade. Contudo, utilizou uma estratégia não muito diferente daquelas empregadas pela situação.

Concorreram às urnas o Partido Republicano, que apresentou chapas pa- 
ra intendente, vice-intendente e sete conselheiros, e a Aliança Libertadora, que também pleiteou os dois primeiros cargos e mais os de cinco conselheiros. Além destas chapas apresentaram-se ainda dois candidatos avulsos aos cargos de membros do Consel ho Municipal.

Registramos satisfeitos que a eleição municipal de domingo correu em absoluta ordem em todas as 54 mesas de que se compõem os 10 distritos do município reinando cordialidade entre os mesários, fiscais e eleitores de ambos os partidos.

A maioria das mesas eleitorais foi fiscalizada pela oposição, sendo que diversos desses fiscais apresentaram protestos alegando a distribuição de chapas a boca de urna. Os fiscais e mesários situacionistas contra-protestaram, contestando essas alegações. ${ }^{33}$

O depoimento do Correio do Povo afirma que não houve perturbações da ordem durante o processo el eitoral. Falava mesmo em "absoluta ordem" nas mesas el eitorais, não fazendo menção a atos fraudulentos ou a constrangimentos aos eleitores. M encionava-se o acompanhamento feito por parte dos fiscais da oposição junto às mesas el eitorais e das queixas desses diante da atividade de distribuição de chapas na boca das urnas. M as lembremos que não existiam cédulas eleitorais oficiais, e cabia a cada eleitor levar, até a urna, o nome dos candidatos em um papel, a chamada 'chapa'. Frente ao contexto, a distribuição de chapas contendo os nomes dos candidatos era quase um imperativo do processo eleitoral, e a própria oposição também se valia desses artifícios para garantir os votos de seus el eitores. Dessa forma, os protestos al egando a distribuição de chapas não se configuravam como uma perturbação, mas como uma necessidade do processo.

A crítica feita ao processo eleitoral como instrumento de legitimação do poder institucional, nesse momento, não recaía sobre sua lisura, mas sobre o percentual dos eleitores que se fizeram presentes ao pleito, pois segundo o redator, o pleito foi "sensivelmente frio", tendo apresentado uma grande abstenção do eleitorado. Para justificar tal percepção, apresentou um cálculo no qual buscava evidenciar a baixa participação do el eitorado inscrito. Para o redator desse jornal mereceu destaque a diferença desse processo frente ao pleito anterior. Como destacado anteriormente, aqui também era evidenciado que antes não houvera disputa, enquanto agora se mencionava uma efetiva concorrência eleitoral entre as chapas da situação republicana e da oposição libertadora.

Pelo resultado final daquele pleito foram el eitos os sete candidatos do Partido Republicano, sendo a lista de conselheiros completada pelos dois no- 
mes que se apresentaram como avulsos, mas que eram identificados com os republicanos. Assim, a oposição foi mantida fora do Conselho M unicipal. M as o que nos chama a atenção nesse resultado não é propriamente a vitória dos candidatos republicanos, e sim a ordem de votações obtidas no interior das chapas. Entre os conselheiros, vê-se que o candidato mais votado foi o nome indicado pela Associação Comercial Varejista. $O$ segundo foi o presidente do Clube Republicano $\mathrm{M}$ arcos de Andrade, e o terceiro, um candidato avulso. $\mathrm{Na}$ outra ponta, os dois últimos consel heiros republicanos el eitos foram justamente os candidatos sem vinculação aparente com as associações políticas. Na nominata da Aliança Libertadora ocorreu um fenômeno semelhante. Embora não tenha sido el eito nenhum de seus candidatos, os mais votados foram justamente os nomes que mais se fizeram presentes às reuniões promovidas nas associações políticas oposicionistas. Da mesma forma, percebe-se que o conjunto de atividades de campanha que se realizaram nesse processo eleitoral teve eco no resultado da votação. ${ }^{34}$

Percebemos então que, ao propor candidatos ligados às associações políticas e profissionais, o PRR projetava para o Conselho M unicipal algumas lideranças desses grupos sociais em troca de angariar simpatias e votos dos eleitores reunidos nessas entidades. Podemos mesmo inferir que o partido estabeleceu uma aliança com esses setores da sociedade para eleger seus líderes partidários locais como Francisco Bento Júnior que, mesmo tendo a menor votação entre os eleitos para o Conselho Municipal, teve prestígio político suficiente para ser escolhido pelos demais el eitos como presidente da mesa desse conselho. ${ }^{35}$

\section{ALBERTO BINS: um NOVO CONSENSO}

Com o súbito falecimento de Otávio Rocha em 1927, o vice intendente Alberto Bins assumiu o posto. Mas o Plano de M elhoramento segue como a base do projeto político administrativo de reformas urbanas. Nessa perspectiva a intendência continuou a execução das obras de urbanização e modernização da cidade. ${ }^{36} \mathrm{As} \mathrm{recém}$ abertas avenidas centrais da cidade receberam os nomes significativos de Avenida Júlio de Castilhos eAvenida Borges de Medeiros. Já Otávio Rocha, o intendente recém falecido, era homenageado com uma rua, uma praça e o primeiro viaduto da cidade, todos no centro urbano. Prosseguiu-se 0 aterramento das margens do Guaíba e iniciaram-se também a urbanização do Campo da Redenção e a arborização de outros espaços de 
lazer, tal como a ampliação do calçamento das vias, da rede de água, de esgoto e de fornecimento de energia elétrica. ${ }^{37}$

Uma vez que teve continuidade o projeto político administrativo interessante aos grupos sociais da cidade que se modernizava, a indicação do nome de Alberto Bins como candidato republicano à intendência no pleito de 1928 surgiu com certa naturalidade, sendo agora acompanhado do nomede Sinval Saldanha, membro da direção partidária, como candidato a vice-intendente. Eleito nesse pleito, foi mantido como prefeito de Porto Alegre após a Revolução de 1930, sendo afastado da chefia do município somente com o Golpe de 1937, após dez anos à frente da gestão dos negócios da municipal idade. ${ }^{38}$ À primeira vista, essa longa administração pode remeter àquela estratégia de sucessivas reeleições vivida na cidade com José M ontaury. Contudo, um olhar mais detido sobre a dinâmica da eleição municipal de 1928 mostra que a conjuntura política daquele momento exigiu das lideranças do PRR uma estratégia diferente para manter o controle do processo político.

O cenário ao final da década de 1920 estava marcado por uma conjuntura estadual particular. 0 projeto da oposição de provocar a alternância no poder estadual se concretizou com a eleição de Getúlio Vargas, e sua posse, em fevereiro de 1927, criou expectativas de alteração das relações políticas no estado. Como observa Paulo Vizentini, o governo estadual efetivamente implementou uma política de aproximação com a oposição com vistas à intervenção unificada das forças políticas do estado na eleição presidencial de $1930 .{ }^{39}$ U ma das estratégias para essa aproximação foi o reconhecimento dos resultados das el eições munici pais por parte do governo estadual. Diferente do governo anterior, Getúlio Vargas, enquanto na Presidência do Estado, não decretou a intervenção nos municípios onde a oposição saía vencedora. Com isso, respeitava-se o Pacto de Pedras Altas, e o processo eleitoral era reconhecido como mecanismo de legitimação para o exercício do poder institucional. D essa forma, no pleito municipal de 1928, mais uma vez colocou-se ao PRR a tarefa de fazer-se vitorioso nas urnas da capital para legitimar o exercício do poder institucional. Para tal reconstituiu a dinâmica da campanha eleitoral anterior, quando a tarefa de legitimação dos candidatos estivera a cargo das associações políticas. Na esteira da modernização urbana e da redefinição das alianças políticas, a vida associativa ganhava mais espaço, projetando-se no campo político como agentes sociais representativos de demandas particulares dos diferentes grupos sociais.

Ingressando na vida política pelas mãos do próprio Júlio de Castilhos, de quem o pai era alfaiate, Alberto Bins mantinha estreitas relações com a comu- 
nidade alemã do estado, constituindo-se mesmo em representante da colônia frente ao Partido Republicano e ao parlamento. A força dessa relação com a comunidade alemã e, por extensão, com significativos grupos da burguesia comercial e industrial da cidade, pôde ser percebida em março de 1924, quando esse grupo social promoveu um abaixo-assinado dirigido ao presidente do estado e chefe republicano Borges de M edeiros, solicitando que incluísse o nome deAlberto Bins na nominata de candidatos a deputados federais, dizendo:

Sem o menor deslumbre de insinuação, sr. Presidente, o candidato à deputação federal que satisfaz as aspirações, tanto do el emento católico como protestante germânico, tanto do comércio como da indústria e da lavoura, é o atual deputado estadual, soldado do Partido Republicano, Sr. Major ALBERTO BINS, este homem que, em todos os tempos, encarnou o verdadei ro sentir da colônia em peso, este homem em que ela sempre confiou, pelos títulos todos ilustres que o recomendam aos seus pares, este homem, enfim, que constitui o símbolo de suas mais el evadas aspirações. ${ }^{40}$

0 texto do abaixo-assinado era extenso e cuidadoso no respeito à hierarquia partidária. N ele, é clara a intenção de evitar o "menor deslumbre de insinuação" que causasse constrangimentos ao líder partidário. M as esse extrato também demonstrava claramente a intenção desses membros da colônia alemã de que Alberto Bins fosse indicado como candidato ao Congresso federal. Contudo, essa candidatura federal pretendida pela comunidade alemã não se confirmou. 0 interessante para a anál ise que está sendo desenvolvida é perceber o desejo desse grupo social de intervir na indicação das candidaturas do Partido Republicano e a estratégia coletiva utilizada para tal.

Para apresentar as candidaturas republicanas para o pleito municipal de 1928 foi novamente preparado um grandeato demobilização partidária. Com essa finalidade, A Federação publicou a convocação para a plenária de proclamação dos candidatos republicanos para o dia 20 de junho. Dessa vez, porém, o lançamento das candidaturas foi antecedido de uma reunião preparatória:

Na sede do "Centro Republicano Julio de Castilhos" haverá também uma reunião dos membros da Comissão Executiva, das comissões distritais e dos "clubes republicanos", a fim de tratarem do mesmo assunto. ${ }^{41}$

O chamado para essa reunião preparatória dirigia-se não apenas à Comissão Executiva Municipal, mas também aos dirigentes das “comissões dis- 
tritais" e dos "clubes republicanos", que no texto do jornal foram chamados de "representantes autorizados da opinião republicana". Ainda que não tenham sido apresentados os nomes dos presentes, entrevemos uma reunião numerosa. I nicial mente, contava com os membros das comissões, que se organizavam nos sete distritos eleitorais da capital. Junto a esses, devem ser incluídos os diretores de pel o menos as nove associações que articularam atividades de campanha ao longo desse processo eleitoral, muito embora tenhamos nota de outras tantas. Ficava evidente que os dirigentes das comissões distritais e dos clubes republicanos passaram a ocupar um local de destaque na vida partidária. A importância desses agentes e a força das suas opi niões podem ser percebidas não tanto pelas resoluções da reunião, mas justamente a partir do que ela não definiu, como mostra o relato publicado pelo jornal A Federação, no dia seguinte:

Os presentes, representantes autorizados da opinião republicana do município, aprovaram sem discrepância os nomes propostos [ para intendente e vice], quejá mereceram também a aprovação do eminente chefe do partido, dr. Borges de M edeiros.

Sobre a chapa de conselhei ros municipais, nada foi resolvido, em definitivo, por não se encontrar ela completamente organizada ainda. ${ }^{42}$

Ao mencionar que "sobre a chapa de consel hei ros municipais, nada foi resolvido, em definitivo", o diário partidário nos coloca frente a uma situação distinta da interpretação que estamos acostumados a realizar sobre o processo político republicano no Rio Grande do Sul. N esse momento, ficava explícito que essa reunião das lideranças locais, dos diretores dos distritos e dos clubes tinha a tarefa de definir os candidatos ao pleito municipal. I sso aponta que o chefe republicano ou não decidiu sobre a totalidade da nominata, ou então não foi acatado em sua indicação. O Ihando de perto a situação descrita, vemos que a autoridade de Borges de M edeiros não era mais tão inconteste, como nos processos anteriores. Além disso, apresenta que a reunião das lideranças políticas locais também não produziu um consenso sobre essa questão. 0 que remete para um possível dissenso entre as lideranças partidárias locais, uma vez que não conseguiram definir conjuntamente os nomes dos candidatos ao consel ho municipal.

No caso particular que estamos estudando, ainda que a estrutura partidária autoritária não fosse questionada ficou evidente que os diretores das associações e dos diretórios distritais não eram meros reprodutores da política 
dos dirigentes partidários. N esse episódio, eles assumiram a posição de agentes políticos responsáveis pela aprovação dos candidatos do Partido Republicano. Foram eles os responsáveis pela indefinição da chapa republicana apresentada à comunidade política de Porto Alegre. A menção a esses acontecimentos traz à tona a importância adquirida pelos dirigentes das associações políticas na disputa el eitoral.

Os reflexos dessa indefinição ainda podem ser percebidos no relato da plenária de lançamento das candidaturas. Na longa nota que A Federação publicou, observamos que, naquele momento, os nomes para os cargos de consel hei ros ainda estavam mal definidos. Ao contrário do que seria de esperar de um ato de lançamento da campanha, o orador responsável por fazer a apresentação dos nomes dos candidatos produziu um discurso tão prolixo quanto vazio. ${ }^{43} \mathrm{O}$ jornal partidário, ao transcrever o discurso nada diz sobrea atuação, representatividade ou capacidade pessoal de cada candidato. 0 destaque do texto recaiu sobre a menção ao "espírito de renúncia", ao desapego às "posições de destaque" como características dos republicanos e de seus candidatos. Usar tais termos no momento da proclamação dos candidatos significava mais que um exercício de retórica. Lembrar da grandeza dos atos de abnegação política num momento de indefinição das candidaturas era mesmo um apelo aos não-contemplados com a indicação para que aceitassem as definições adotadas.

Outra particularidade significativa nesse processo foi a demora para essa nominata ser divulgada nas páginas de A Federação. A penas no dia 26 de junho, ou seja, uma semana após a assembléia de lançamento, o jornal voltou a mencionar os nomes dos candidatos republicanos ao pleito municipal:

Os cidadãos que constituem essa chapa, quer pela significação individual, quer pelo elemento social que representam, oferecem as mel hores garantias de um legislativo capaz e eficiente na gestão dos negócios do município de Porto Alegre.

As classes liberais aí estão, dignamente corporificadas na inteligência e cultura dos Drs. Oswaldo Vergara e Camilo M artins Costa; a engenharia terá no Dr. Adolpho Stern um representante legítimo, que levará ao Conselho a contribuição de um saber incontestável; o comércio e a indústria em todas as modalidades, terão voz autorizada no Conselho, por intermédio de Germano Petersen, Octávio Barreto e Luiz Correa Lima; e os operários, do mesmo modo, por intermédio de Francisco Xavier da Costa, esforçado lidador dos homens do trabalho.

Estamos, portanto, de parabéns: o problema da sucessão intendencial de Porto Alegre, resolveu-o o partido republicano sob a orientação suprema do ínclito 
Borges de M edeiros, com felicidade e acerto inegáveis, assegurando a capital do estado um quadriênio de labor, de dignidade, de progresso e de ordem... ${ }^{44}$

N essa nota, finalmente se têm informações que nos permitem entender os liames do processo que se está acompanhando. Diferentemente da descrição anterior, agora os nomes eram apresentados pelas suas qualidades profissionais e pessoais que os credenciavam para a Intendência e para o Consel ho Municipal. Ficou explícito que os candidatos deviam representar não apenas o partido, mas também um grupo social para assim oferecer "as melhores garantias de um legislativo capaz e eficiente". A vinculação social dos candidatos, tal como nos pleitos anteriores, foi reafirmada como uma condição para a indicação de um nome ao consel ho municipal. Na seqüência da nota, ficou reconhecida a existência de um "problema da sucessão intendencial", antes apenas sombreado. Evidentemente, não se conhece a exata dimensão dessa querela. Não se tem como aferir o calor desse debate, nem mesmo as posições ali tomadas. M as já há indícios suficientes para entender que ela passou pela definição dos candidatos ao Conselho M unicipal, visto que somente após estar resolvido esse "problema da sucessão", o jornal divulgou os nomes dos candidatos para o Conselho Municipal.

Agora, eram divulgados sete candidatos para as nove vagas de consel heiros municipais, quando na plenária se falava em oito nomes. Para entender a dificuldade em retirar o nome de Frederico Trein devemos considerar que cada candidatura representava um grupo social. Essa redução da chapa republicana implicava a definição de qual seria o grupo excluído da representação no conselho, o que explicaria a dificuldade de acordo entre os republicanos, no momento de definição da nominata. Tratando-se de uma divergência interna dos republicanos, justificava-se ainda a forma sumária com que essa questão dos conselheiros foi tratada na plenária e mesmo a demora na divulgação dos nomes no jornal republicano. Mas para nossas reflexões interessa evidenciar que os dirigentes das associações políticas e dos diretórios distritais presentes à primeira reunião efetivamente interferiam nesse debate, deixando claro que não eram agentes de todo manobrados pela direção partidária. N ão somos ingênuos em acreditar que decisões de tal ordem se faziam sem a pressão das lideranças partidárias maiores. Efetivamente, o campo político não é um espaço social de iguais. M as salientamos que os diretores das associações não estavam totalmente submetidos à disciplina partidária.

Do outro lado do cenário político da capital, os libertadores também enfrentaram dificuldades em definir sua participação no processo eleitoral de 
1928. As informações a que se tem acesso sobre a movimentação entre os partidários da oposição são mais precárias do que as referentes aos republicanos. Contudo, quando se entende o campo político como um espaço social de regularidades, podemos nos valer do entendimento construído sobre a dinâmica interna do Partido Republicano para lançar luzes sobre os poucos indícios das ações da oposição.

Um primeiro aspecto sobre a mobilização da oposição era mesmo a pouca informação sobre suas atividades. Talvez esse abafamento fosse motivado pela falta de um jornal oposicionista que se ocupasse em divulgar essas atividades com a mesma intensidade que o órgão republicano. Ainda esse jornal nos permite acompanhar timidamente aquilo que devia ter sido um rico debateno seio da oposição, sobre a participação no pleito municipal de 1928. Deacordo com as notas daquele jornal, surgiram duas correntes de opinião entre os oposicionistas da capital com relação à participação nas eleições municipais.

O Diretório do Partido Libertador de Porto Alegre, em reunião realizada, há dias resolveu, como já noticiamos concorrer ao próximo pleito para a renovação da administração da capital.

Em cumprimento desta resolução, foi marcado o dia de amanhã para a eleição prévia dos candidatos, havendo uma corrente favorável à apresentação de uma chapa, apresentando-se aos cargos de intendente e vice-inten dente e de alguns consel heiros e, outra apenas, para consel heiros ${ }^{45}$

Através dessa nota confirma-se que é somente pouco mais de um mês antes da votação que a oposição decidiu concorrer ao pleito municipal. E para definir sobre a dimensão dessa participação foi convocada uma prévia partidária. Ou seja, tal como entre os republicanos, também no Partido Libertador o debate sobre as candidaturas saiu do círculo das lideranças e passou a mobilizar o conjunto dos partidários. Esse trecho deixa evidente que havia um grupo de oposicionistas que desejava disputar os cargos de intendente e vice, ao passo que outros desejavam apresentar apenas os nomes para as vagas do Conselho M unicipal. Pode-se considerar que divergências da oposição eram recorrentes frente ao seu fracionamento programático. Porém, levar a solução desse embate a uma prévia indica, num sentido, que o nível de dissenso sobre o tema era grande e conflituoso. N outra direção vemos que a participação do conjunto dos partidários na definição das candidaturas era uma prática social que passava a ser valorizada.

Sobre essa prévia el eitoral realizada pelos libertadores, o próprio Correio 
do Povo informava que, mesmo com o mau tempo, a votação esteve "bastante concorrida". ${ }^{46} \mathrm{~N}$ ão se tem nenhum indicativo do número de eleitores ou de votos obtidos pelas teses concorrentes. Sabemos apenas que a prévia organizada pelo Partido Libertador da capital decidiu pela apresentação de candidatos para a intendência e vice-intendência, acompanhados de dois candidatos ao Conselho M unicipal, apontando que os partidários da oposição na capital desejavam um enfrentamento eleitoral com os candidatos republicanos.

No dia seguinte, contudo, o Diretório do Partido Libertador de Porto Alegre reuniu-se para debater a participação da oposição no pleito municipal. Diferentemente do relato das reuniões anteriores, nesse momento foram apresentados os nomes das lideranças oposicionistas presentes à reunião. A referência nominal a esses personagens pode ser entendida como reforço de autoridade às decisões dessa reunião para se contrapor à decisão tomada antes, pois, desconsiderando o processo de prévias, essa reunião do diretório decidiu pela não-apresentação de candidatos ao executivo municipal. Foram mantidos apenas os dois candidatos ao Consel ho M unicipal: Basil Sefton e Pio Contreras. Dessa forma, o diretório da oposição optou por apresentar apenas o número de candidatos deixado em aberto pela chapa republicana, evitando o enfrentamento eleitoral.

M as o que se destaca como particular nesse processo é a disputa no interior da oposição. De um lado, estava uma determinada maioria dos partidários que participaram da prévia votando pela chapa completa; de outro, os dirigentes que decidiram pela apresentação de candidaturas na exata medida das vagas não preenchidas pela nominata republicana. Enquanto os primeiros desejavam o enfrentamento eleitoral, percebe-se, no movimento dos últimos, a tentativa de evitar o confronto político, que poderia tumultuar a aproximação com o governo do estado. Essas duas correntes possuíam forças e poderes distintos dentro do Partido Libertador. A tese do enfrentamento aparentemente tinha maior capacidade de mobilização e, por isso, agiu através de uma prévia. Já os contrários ao enfrentamento aparentemente detinham o controle das estruturas burocráticas do partido e as utilizaram para reverter a posição. Ou seja, tal como ocorrido com os republicanos no momento de definição dos candidatos ao consel ho, percebemos que, também no seio da oposição, lideranças e liderados divergiam e pressionavam uns aos outros nas definições das disputas políticas.

M esmo isso não pôs fim ao impasse sobre a participação da oposição no pleito. Em 24 de julho, véspera do pleito, chegou à cidadea notícia da vitória doscandidatosoposicionistas para asintendências deDom Pedrito eCachoeira. 
O Correi o do Povo afirmava que, "como em outros pontos do Estado", os libertadores da capital, quatro dias antes da votação, também resolveram realizar uma manifestação pública de comemoração dessa vitória el eitoral. ${ }^{47}$ Pela nota do jornal vemos que os estudantes libertadores organizaram uma passeata seguida de comício no centro da cidade e, chegando à sede do Partido Libertador, foi proferida uma série de discursos da bancada onde se alternaram oradores libertadores. Essa manifestação deixou claro que, tal como osrepublicanos realizavam atividades cívicas em frente ao monumento a Castilhos, a oposição também utilizava a estratégia de mobilização de rua para publicizar suas posições. Outra aproximação que se deve fazer entre a postura da oposição e a da situação é justamente a estratégia associativa, visto que após essa definição pelos cargos que se disputaria, teve início uma série de atividades de campanha promovidas pelas associações políticas oposicionistas.

Como esperamos ter deixado claro, o consenso sobre a candidatura de Alberto Bins para a Intendência Municipal ocultava o dissenso sobre os rumos da política municipal, tanto entre os republicanos como entre a oposição. Entre os republicanos havia a indefinição de quais nomes deveriam compor a chapa republicana ao Conselho Municipal. Já a oposição debatia se deveria compor uma nominata completa que de fato disputasse o pleito ou se apenas apresentaria candidatos aos postos não preenchidos pela chapa republicana, facilitando a aproximação política vivida em nível regional.

Nas edições do dia seguinte à votação, os jornais publicaram suas percepções sobre o processo el eitoral. Por esses textos, observamos que não recaíram suspeitas de fraudes sobre o pleito. Ao contrário, A Federação falava mesmo da cordialidade entre os concorrentes, e o Correio do Povo também apontava para o respeito entre os partidos concorrentes. N essa folha tem-se ainda a transcrição do depoimento de um fiscal da oposição que testemunhava pela lisura do processo eleitoral:

$\mathrm{Na}$ 25ạ secção, onde funcionou como presidente da mesa o Dr. Antônio P. Louzada, o fiscal da oposição fez o seguinte elogio:

Sr. Presidente. Como fiscal do Partido Libertador tenho o prazer de declarar que, no decorrer dos trabalhos el eitorais, notei em todos os membros da referida mesa a maior correção, dando lugar a que o pleito se realizasse com a máxima cordialidade. ${ }^{48}$

Não se pode generalizar esse depoimento, mas também não se pode desconsiderá-lo como uma fala significativa sobre o processo. "O prazer de de- 
clarar" expresso no texto deve ser percebido no contexto de longa queixa da oposição pela efetivação de pleitos legalmente justos. Dessa forma, podemos ler nesse testemunho a satisfação de um vencedor, não do pleito, mas da disputa simbólica travada pela oposição em defesa de uma determinada concepção do processo eleitoral que agora se materializava.

A esmagadora vitória final de Alberto Bins, por 7.472 votos frente aos 331 votos de Lafayete Cruz e os 318 votos de Carlos Prestes, não surpreende, visto essas candidaturas oposicionistas não terem realizado campanhas. Da mesma forma, a eleição dos candidatos republicanos ao Conselho M unicipal, todos com mais de 7 mil votos, não causou estranheza. M esmo assim, devemos interpretar com maior cuidado o significado desses resultados. Uma primeira observação se refere à votação de Frederico Trein para o Conselho Municipal. Deve-se lembrar que o nome desse republicano constava da primeira lista divulgada na plenária de lançamento das candidaturas republicanas. M as, após a resolução do "problema da sucessão intendencial", foi retirado da nominata. Assim, enten demos que, embora republicano, ele tenha concorrido como candidato avulso naquele pleito. Aparentemente, a solução anunciada para o problema da sucessão não foi eficientemente encaminhada, ou talvez, não tenha sido tranqüilamente aceita pelo conjunto dos eleitores do partido. Ao mesmo tempo, o M al. M esquita, que era apontado pela oposição como uma antiga liderança republicana e também concorreu como avulso, não se el egeu. Assim, nos aponta que essa desobediência partidária não era dispersa.

Uma segunda consideração recai sobre os dois nomes oposicionistas que obtiveram votações expressivas para o cargo de intendente. Lembremos que, pela legislação em vigor, não havia a necessidade de registro prévio de candidaturas, assim os nomes de Lafayete Cruz e Carlos Prestes poderiam ser votados independentemente de seus desejos pessoais ou das objeções partidárias. Para entendermos o significado dessas votações devemos destacar que Lafayete Cruz, 331 votos, era um dos presentes à reunião do Diretório Libertador que havia suspendido as candidaturas oposicionistas ao executivo municipal. $\mathrm{N}$ ão se sabe sua posição naquele debate, mas tem-se presente que a menção de seu nome naquele momento o destacava como al guém de prestígio junto aos correligionários. Já Carlos Prestes, 318 votos, era uma liderança do movimento tenentista que questionava as estruturas políticas da República. Sua votação, bem próxima da obtida pela oposição, demonstrou que esse movimento de contestação à ordem político-social vigente encontrava acolhimento na comunidade política local. De outra parte, Gabriel M oacyr, que obteve 642 votos para a vice-intendência, também era uma das lideranças da oposi- 
ção local. Ele estava presente ao ato em comemoração à vitória em Dom Pedrito e Cachoeira e se pronunciou aos opositores que ali se manifestavam. Sua votação para o cargo de vice-intendente esteve bem próxima da soma dos votos dados aos dois candidatos opositores à intendência. M ais curiosa fica a si tuação quando lembramos que nenhum desses nomes havia sido lançado publicamente como candidato. Ao contrário, o Diretório do Partido Libertador tinha decidido por não disputar os cargos executivos.

Votações tão próximas entre si para os cargos do executivo são indícios de que elas constituíam diferentes estratégias de intervenção na forma de votação. Em desacordo com a decisão tomada pela Comissão Executiva parecem mais uma disfonia entre os diferentes setores da oposição. A documentação não nos permite afirmar com certeza o significado desses números, mas ainda assim nos atrevemos a aventar al gumas possibilidades interpretativas. Uma explicação possível para essa votação díspar entre os diferentes candidatos da oposição seria apontar para uma falta de organização por parte dos oposicionistas. Contudo, ao lembrar os lances políticos e as atividades promovidas durante a campanha, percebemos que a oposição não estava desarticulada. Dessa forma, preferimos inferir que tais números indicam a existência de diferentes estratégias no interior dos eleitores da oposição.

Se for tomado o total de votos atribuídos aos consel heiros da oposição - 9.845 - e dividirmos pelos nove votos que cada eleitor poderia acumular em um ou mais candidatos, podemos estimar que a oposição levou às urnas algo próximo de mil eleitores, e não apenas os trezentos votos para intendente ou os sei scentos para vice-intendente. Nessa hipótese, cerca de trezentos eleitores seguiram o projeto da prévia do Partido Libertador e votaram em uma chapa completa de libertadores: intendente e vice, acumulando seus votos em dois consel heiros. Outros trezentos el eitores, muito provavelmente não-libertadores, decidiram por votar no candidato ligado ao movimento tenentista para intendente e no candidato libertador para vice, o que explicaria seus seiscentos votos. Já um terceiro grupo de aproximadamente quatrocentos eleitores teria seguido as instruções do diretório do Partido Libertador e votou apenas nos candidatos ao Conselho Municipal. Independentemente da precisão desse cálculo, os resultados obtidos pelos candidatos oposicionistas nos permitem perceber que houve diferentes comportamentos eleitorais. Podemos mesmo ponderar que aqueles diferentes projetos de participação no pleito municipal que se manifestaram no momento de definição das candidaturas permaneceram latentes, mesmo depois das decisões em contrário tomadas pelas lideranças partidárias. 
H ouve uma intenção, portanto, das lideranças da situação e também da oposição de produzir um consenso, entre seus el eitores, sobre como conduzir a votação. M as isso não ocorreu. N em os chefes da oposição evitaram a emergência das candidaturas à intendência e vice-intendência, nem os dirigentes republicanos conseguiram impedir a inclusão de um oitavo nome na lista republicana de conselheiros. Tanto de um lado como de outro é possível identificar que essa movimentação foi promovida à revelia das orientações das lideranças políticas republicanase oposicionistas, fato queevidencia a existência de espaços de decisão diferentes das plenárias partidárias aqui apresentadas, controladas pelas lideranças.

\section{O SIGNIFICADO DAS ELEIÇÕES}

Como esperamos ter deixado transparecer nesta leitura das mobilizações eleitorais realizadas em Porto Alegre durante a década de 1920, não ocorreu apenas uma troca dos nomes nos postos da administração municipal. Houve, sim, uma alteração da forma como se estabel ecia a disputa e legitimação do exercício do poder institucional frente às transformações sociais e econômicas típicas do processo de modernização. Julgamos que mais do que os resultados eleitorais, são as representações e práticas utilizadas para agir, codificar e interpretar o processo político que permitiram perceber as rupturas e continuidades desse processo.

No processo de transformações socioeconômicas e de questionamento das estruturas de dominação, a possi bilidade de atuação no interior das associações políticas tanto republicanas como oposicionistas promoveu uma redefinição das práticas sociais ligadas ao processo el eitoral. Assim, respondeu simultaneamente ao esvaziamento das relações de dominação coronelistas, evitando uma ruptura total com o mandonismo local e com as práticas clientelistas. Aten deu as demandas sociais decorrentes da modernização das relações sociais, abrindo espaços para os grupos sociais urbanos participarem do processo eleitoral. As associações se constituíram em um espaço de sociabilidade onde se socializavam as representações e práticas legítimas para os membros dessa comunidade codificar e interpretar eagir no campo político.

Como vimos, em 1920 José M ontaury foi lançado como candidato a intendente por Borges de M edeiros sem maiores mobilizações ou justificativas. Ele era o intendente já el eito por sete vezes sucessivas, o eterno candidato republicano ao cargo. A campanha, nessa el eição, limitou-se aos artigos publi- 
cados por A Federação, pois a legitimidade de seu nome e dos candidatos ao Consel ho Municipal dependia basicamente da escolha do líder partidário. Em 1924, por força do Pacto de Pedras Altas, ficou vedado o estatuto da reel eição que colocava em xeque a estratégia de manutenção do poder institucional montada pelo borgismo. Ao mesmo tempo o el eitorado urbano se diversificava por conta do processo de modernização econômica. Nesse momento explicitou-se ao PRR a necessi dade de rearticular os mecanismos de legitimação social do controle do aparelho estatal. Já para a oposição emergia a possibilidade de erigir estruturas de mobilização capazes de disputar os cargos eletivos.

Frente a essa situação, a concorrência eleitoral deixou de ser um jogo restrito às lideranças partidárias, transferindo-se para uma rede de associações políticas que se responsabilizaram pelas atividades de campanha el eitoral. Dessa forma, passou a envolver ativamente um conjunto de novos agentes. Atividades como a grande plenária de aclamação da candidatura de O távio Rocha e demais candidatos ao Consel ho M unicipal de 1924 significou não apenas a ascensão de novos nomes aos postos municipais, mas a articulação de novas estratégias de arregimentação e mobilização el eitoral, a construção de espaços de sociabilidade política nos quais emergiam representações e práticas socialmente legítimas para codificar e interpretar o processo político. Essa alteração tornou-se mais clara em 1928, quando os membros das associações políticas republicanas não apenas aprovaram as candidaturas, mas procuraram mesmo interferir na definição dos nomes dos candidatos.

Entre os partidários da oposição, de forma muito semelhante, também surgiram pressões por posi ções mais agressivas no enfrentamento el eitoral. Lembremos que em 1920 a oposição não apresentou candidatos, possivelmente para não legitimar um processo que julgava fraudulento. Já no pleito de 1924 apresentou uma chapa completa para o pleito municipal. E em 1928 o debate no interior da oposição se referia ao grau de enfrentamento eleitoral conveniente a um momento de aproximação política. Julgamos que esses diferentes posicionamentos já evidenciam as diferenças de postura da oposição ao longo do período.

A continuidade do PRR à frente da Intendência de Porto Alegre, ao longo da década de 1920, portanto, não pode ser entendida como a manutenção de uma política administrativa ou mesmo da manipulação dos resultados eleitorais. Diferentemente disso, percebe-se que o PRR legitimou sua supremacia política através de estratégias el eitorais distintas para conjunturas políticas também diferentes. Num primeiro momento, como visto, os candidatos eram 
definidos pelas lideranças partidárias e apresentados à comunidade. N os processos seguintes, os candidatos eram apresentados como escolhas coletivas aclamadas pelo conjunto dos partidários. Por fim, os partidários assumiam posturas mais autônomas e passavam a propor candidaturas à revelia do interesse das lideranças partidárias.

Não foi por acaso que, em meio a essa crise hegemônica, o PRR substituiu o "eterno intendente" pelo nome de Otávio Rocha. Também não foi coincidência a posterior permanência de Alberto Bins como intendente. Longe de ser uma troca da guarda, entendemos que esse processo representou a emergência de uma estratégia distinta de intervenção no campo político, uma capacidade das lideranças políticas em adequar suas estratégias de mobilização eleitoral às demandas sociais e políticas decorrentes do cenário urbano em transformação.

Sendo fato que as lideranças partidárias tinham forte poder de definição dos encaminhamentos tomados, também fica evidente que surgiam instâncias de mediação política entre esses e os partidários. Sendo evidente que o PRR acatou o acordo de Pedras Altas e disputou os pleitos através do voto, como queriam os liberais, também ficou claro que esses utilizavam as práticas e representações políticas o peradas pelos republicanos nas disputas el eitorais. Pelo descrito neste estudo de caso, fica a percepção de que tanto a oposição como os republicanos articularam um conjunto de representações e práticas sociais para codificar, interpretar e agir no campo político. A base dessa cultura política estava na articulação de uma rede de associações que se disseminou na cidade. Através delas montou-se uma estrutura de arregimentação e mobilização do el eitorado urbano como forma de legitimar o exercício do poder institucional. Ao mesmo tempo esses espaços se fortal eciam como mecanismos de interferência dos grupos sociais urbanos ali representados nas decisões do campo político. Tendo as associações como instrumentos de arregimentação e mobilização eleitoral, o PRR restabeleceu as condições para a manutenção do poder institucional na capital que se modernizava.

NOTAS

${ }^{1}$ BAKOS, M. Porto Alegre e seus intendentes. Porto Alegre: EDIPU CRS, 1996.

2 M AROZEN E, L. A. G. Espaços de sociabilidade e memória: fragmentos da "vida pública" porto-alegrense entre os anos 1890 e 1930. Porto Alegre, 1994. Dissertação (M estrado em 
História) - Instituto de Filosofia e Ciências Humanas, Pontifícia Universidade Católica do Rio Grande do Sul, 1994.

${ }^{3}$ FRAN CO, S. da C. A pacificação de 1923: as negociações de Bagé. Porto Alegre: Ed. Universidade/UFRGS/EST Ed., 1996.

${ }^{4}$ PICCOLO, H. I. L. O Partido Republicano Rio-Grandense e os alemães no Rio Grande do Sul. In: SIM PÓSIO DE HISTÓRIA DA IMIGRAÇÃO E COLONIZAÇÃO ALEM Ã NO RIO GRANDE DO SUL (5). Anais... São Leopoldo, 1989, p.21-36, p.32.

${ }^{5}$ GERTZ, R. 0 aviador e o carroceiro: política, etnia e religião. Porto Alegre: EDIPU CRS, 2002.

${ }^{6}$ SAN I, G. Cultura política. In: BOBBI O, N . et al. Dicionário de política. Brasília: Ed. UnB, 1992, p.306-8.

${ }^{7}$ RÉM ON D, R. Por uma história política. Rio de Janeiro: Ed. UFRJ/Ed. FGV, 1996.

${ }^{8}$ PALM EIRA, M ; GOLDM AN , M . Antropologia, voto e representação política. Rio de Janeiro: Contra Capa, 1996.

${ }^{9}$ LEAL, V. N. Coronelismo, enxada e voto: o município e o regime representativo no Brasil. 2.ed. São Paulo: Alfa-Omega, 1975. [1.ed. 1949]

${ }^{10}$ NICOLAU, J. M . H istória do voto no Brasil. Rio de Janeiro: Zahar, 2002.

${ }^{11}$ TRIN DADE, H. Rio Grande da América do Sul: partidos e eleições. Porto Alegre: Ed. da Universidade/U FRGS/Sulina, 1991.

${ }^{12}$ FRANCO, S. da C. A pacificação de 1923: as negociações de Bagé. Porto Alegre: Ed. Universidade/U FRGS/EST Ed., 1996.

${ }^{13}$ Correio do Povo, Porto Alegre, 28 set. 1924, p.3.

${ }^{14}$ DIRECTORIA GERAL DE ESTATÍSTICA. Synopse do recenseamento realizado em 10 de setembro de 1920. Rio de Janeiro: Typ. da Estatística, 1925.

${ }^{15}$ Os dados dos censos de 1920 e 1940 não possuem os rigores técnicos das pesquisas atuais, e devem ser vistos com ressalvas. Contudo, não possuímos números melhores para comparações estatísticas da população brasileira. Esses dados populacionais são os mesmos utilizados por autores como Victor Nunes Leal, Raymundo Faoro, Joseph Love e J osé Murilo de Carval ho. Os exercícios de composição do eleitorado aqui apresentados também são inspirados em estratégias utilizadas por esses autores.

${ }^{16}$ GUERREIRO RAM OS. A crise do poder no Brasil: problemas da revolução nacional brasileira. Rio de Janeiro: Zahar, 1961, p.32. Os mesmos dados são utilizados por: CARVALHO, J. M. de, Os três povos da República. In: CARVALHO, M . A. R. de (Org.) República no Catete. Rio de Janeiro: Museu da República, 2001-b, p.61-87; LOVE, J. 0 regionalismo gaúcho. São Paulo: Perspectiva, 1978; FAORO, R. Os donos do poder: formação do patronato político brasileiro. 8.ed. São Paulo: Globo, 1989. [1.ed. 1957] 
${ }^{17}$ A Federação, 21 ago. 1920, p.1.

${ }^{18}$ A Federação, 21 ago. 1920, p.5.

${ }^{19}$ FÉLIX, L. O. Coronelismo, borgismo e cooptação política. Porto Alegre: M ercado Aberto, 1988.

${ }^{20}$ A Federação, 24 ago. 1920, p.1.

${ }^{21}$ Correio do Povo, 28 set. 1920, p.4.

${ }^{22}$ A Federação, 29 set. 1920, p.21.

${ }^{23}$ A Federação, 29 set. 1920, p.17.

${ }^{24}$ SPALDIN G, W. Pequena história de Porto Alegre. Porto Alegre: Sulina, 1967, p.175.

${ }^{25}$ M ONTEI RO, Ch. Porto Alegre, urbanização e modernidade: a construção social do espaço urbano. Porto Alegre: EDIPU CRS, 1995.

${ }^{26}$ A Federação, 11 jul. 1924, p.1.

${ }^{27}$ Sobre o uso dos símbolos pátrios pelos positivistas, ver: CARVALHO, J. M . de. A formação das almas. São Paulo: Companhia das Letras, 1990, p.133.

${ }^{28}$ A Federação, 15 jul. 1924.

${ }^{29}$ A Federação, 15 jul. 1924, p.1-2.

${ }^{30}$ Correio do Povo, 10 jun. 1924, p.1.

${ }^{31}$ Correio do Povo, 23 set. 1924, p.1.

${ }^{32}$ Correio do Povo, 13 set. 1924, p.4.

${ }^{33}$ Correio do Povo, 30 set. 1924, p.6.

${ }^{34}$ Ata do Conselho Municipal de 2 out. 1924.

${ }^{35}$ Atas do Conselho M unicipal. Porto Alegre: AH M M V.

${ }^{36}$ Sobre a trajetória política deAlberto Bins ver a obra de: FAUSEL, E. Alberto Bins: o merlense brasileiro. São Leopoldo: Rotermund, s.d., p.12.

${ }^{37}$ M ONTEIRO, op. cit., 1995.

${ }^{38}$ SPALDING, op. cit., 1967.

${ }^{39}$ VIZENTINI, P. F. A crise dos anos 20. Porto Alegre: Ed. Universidade/U FRGS, 1992, p.52.

${ }^{40} \mathrm{C}$ orrespondência de Borges de M edeiros, 24 mar. 1924.

${ }^{41}$ A Federação, 16 jul. 1928, p.4.

${ }^{42}$ A Federação, 19 jul. 1928, p.4.

${ }^{43}$ A Federação, 21 jun. 1928, p.1.

${ }^{44}$ A Federação, 26 jun. 1928, p.1. 
Ricardo de Aguiar Pacheco

${ }^{45}$ Correio do Povo, 14 jul. 1928, p.12.

${ }^{46}$ Correio do Povo, 17 jul. 1928, p.14.

${ }^{47}$ Correio do Povo, 25 jul. 1928, p.16.

${ }^{48}$ Correio do Povo, 16 ago. 1928, p.14.

Artigo recebido em 02/2005. Aprovado em 10/2005 